Aiqing Wang ${ }^{1}$

DOI 10.31902/LL.2021.8.1c

\title{
TOWER OF MYRIAD MIRRORS: THE FIRST BL ‘QUICK TRANSMIGRATION’ NOVEL?
}

\begin{abstract}
Journey to the West is adulated as one of the Four Great Classical Novels in China, which has inspired a veritable cornucopia of sequels and adaptations. Tower of Myriad Mirrors (aka A Supplement to Journey to the West) composed during late Ming (1368-1644) is one of the three most illustrious sequels in pre-modern literature, in that it is characterised by vivid imagination and creativity, Buddhist ethos and philosophical thoughts, as well as biting satire on political reversals and societal predicaments in the 17th century. More significantly, Tower of Myriad Mirrors manifests psychological insights and features enigmatic dreams, which might have inspired a subgenre dubbed as 'Quick Transmigration' in China's online literature. To be more specific, Tower of Myriad Mirrors is parallel to web-based BL (Boys Love) fiction under the category of Quick Transmigration, in terms of their analogous settings, storylines and characters. In this sense, Tower of Myriad Mirrors can be regarded as a prototypical BL novel concerning 'quick transmigration'.
\end{abstract} Boys Love

Key words: A Supplement to Journey to the West, classical novel, online fiction, time travel,

\section{Introduction}

The 100-chapter novel 西游记 Xiyouji 'Journey to the West' or 'Records of the Westward Journey', which is overwhelmingly ascribed to 吴承恩 Wu Cheng'en (ca 1506-1582) (Hsia, 2015: 108, Wall 2017), recounts an arduous and eventful pilgrimage of a Buddhist monk 玄牀 Xuanzang (aka 唐三藏 Tang Sanzang, 602-664 AD) to India in attainment of sacred scriptures (Wang \& Humblé, 2018; Wang et al., 2019). Journey to the West is marked by cultural and religious components (Plaks 1977), in that it encompasses the indigenous Confucianism and Taoism as well as the Sinicised Buddhism of alien provenance, especially Buddhist allegory (Bantly, 1989) exemplified by an extended allegorical commentary on the duality of emptiness and form of the classic Heart Sütra (Hui, 2015). Moreover, this masterpiece 'represents the inclusion of moral and ethical values in the evolutionary process permeating the universe and the vindication of man's potential of moral metamorphosis and transcendence to a higher plane of existence and ultimate immortality through absolute devotion to the scourging of evil and the exaltation of good' (Xia, 2001: 252). By virtue of its artistic merit and literary renown, Journey to the West has been granted the ultimate accolade as one of the Four Great Classical Novels (四大名著 Sida Mingzhu) of Chinese literature (Shep, 2011; Wang, 2011).

The popularity of Journey to the West has witnessed a profusion of sequels and adaptations in pre-modern China, exemplified by three most renowned literary works, viz. an anonymous 100-chapter 续西游记 Xu Xiyouji 'Sequel to Journey to the West' (Trans. Mine) arguably composed by a scholar 兰茂 Lan Mao circa the Ming dynasty (1368-1644) (Liu, 1984, Sang 2014; Zhang, 2019), an anonymous 40-

${ }^{1}$ Lecturer at the University of Liverpool. 
chapter 后西游记 Hou Xiyouji 'After the Journey to the West' composed circa late Ming or early Qing (1644-1912) (Liu, 2020; Zhang, 2020), as well as a 16-chapter 西 游补 Xiyou Bu 'Tower of Myriad Mirrors' or 'A Supplement to Journey to the West' (Trans. Lin and Schulz 1978: 6) composed by 董说 Dong Yue (aka Tung Yueh, 16201686) or arguably his father 董斯张 Dong Sizhang (Fu, 1989, 2006; Han, 2014).

As indicated by its Chinese title 'A Supplement to Journey to the West', the novel Tower of Myriad Mirrors (henceforward Mirrors) also falls into the genre of fantasy travelogues and is inspired by the phenomenal masterpiece Journey to the West, including its original characters and narration frame (Schulz, 1978; Chu, 1997).

In the narrative, upon leaving the Flaming Mountain, the Monkey, i.e. Monkey King or 孙悟空 Sun Wukong, is trapped in a hallucinatory world of mirrors evoked by Qing Fish, a monster epitomising desire and a negative force proportionate to the Monkey's innate morality (Ouyang, 2015). Through a tower of myriads of mirrors and in disparate identities, the Monkey embarks an array of adventures to various time points, ranging from the immemorial Qin (221-206 BC) dynasty to the Song (960 AD-1279) dynasty that is preceded by the story's setting, i.e. the Tang dynasty (618-907 AD). Upon returning to his own era, the Monkey discovers that his master, the Priest, defies the abstinence from sex and becomes a general, and the Monkey is entangled in a gargantuan war, during which he encounters his own offspring ( $\mathrm{Fu}$, $1989,2006)$. In the end, the Monkey is awakened by the original time-traveller and kills the Qing Fish as the embodiment of desire that entraps his altruism (Miao, 1991: 478-479; Wang, 2015: 522-523), thereby eliminating the negative traits from his psyche or self (Li, 2004: 103).

Composed under the reign of the Chongzhen Emperor (1611-1644), Mirrors satirises the status quo (Wang, 2014) and casts aspersions on a quagmire of political reversals and societal predicaments (Liu, 1984; Wang, 1999; Wang, 2015: 522-523), via adaptation of legions of fictional and historical personages in a fantastical and dramatic manner (Dong, 2015; Zhao, 2020).

Mirrors illuminates Buddhist teachings and precepts (Zheng, 2018; Gao \& Jin, 2020; Li, 2021), in that it illustrates human vulnerabilities to temptation (Chu, 1997) and adopts Buddhist philosophical conceptions of reincarnation and emptiness $(\mathrm{Su}$, 2018). Notwithstanding salient Buddhist ideology, Mirrors is featured by a humanistic perspective and defiance against the Buddhist denigration of earthly existence manifested by Journey to the West: in Journey to the West, the world transfers from shapes and sounds into serenity and enlightenment, whereas Mirrors highlights senses and emotional attachments and entanglements (Chu, 1997). To be more specific, the Monkey is adapted into a multi-faceted character possessing emotions and desires such as consternation and dread, parallel to a quotidian human being, rather than the valiant, optimistic and invincible hero as depicted in the original novel; analogously, other Buddhist characters in Mirrors are also characterised by secular mentality and comportment (Ouyang, 2015; Hua, 2019). Furthermore, the narrative exhibits psychological insights that the one-to-one relationship between mirrors and worlds encapsulates a state of mind, viz. 'a representation of the mind at work in the phenomenal world', which means all 
characters in the dream are expressions of the protagonist's mind and ego (Li, 2004: 105).

As for its narrative aptitude, as acclaimed by one of its translators, '[t]he treatment of dreams in The Tower of Myriad Mirrors goes beyond convincing descriptions to arrive at an intuition of the psychological functions of dream which anticipates the discoveries of modern depth psychology', and '[e]qually unparalleled within Chinese fiction is the novel's structure, a succession of shifting perspectives that matches the fluctuating settings and time plans of the dreamscape' (Schulz, 1978: 7). The protagonist's absorption into dreams and dream psychology are enigmatic, subtle and modern (Hsia \& Hsia, 1968, Hsia, 2004: 430; Hsia, 2015: 188, $\mathrm{Li}, 2015)$, in that 'the creation of dreams, dreams with features familiar to dreamers all over the world: distortions, discrepancies, inconsequence, irrelevance, and preposterous happenings imbued with emotional tensions' (Hsia, 1968: 241).

As a consequence, Mirrors is adulated by intellectuals such as 鲁迅 Lu Xun (aka 周树人 Zhou Shuren, 1881-1936), an illustrious pioneer of modern Chinese literature (Yu, 2006: 125; Tambling, 2007: 1-3; Jones, 2011; Cheng, 2013) and a leading intellectual in the 1919 May Fourth Movement (Sun, 1986; Harpham, 2013; Wang, 2016) (Example (1)).

(1) 其造事遣辞, 则丰赡多姿, 恍忽善幻, 奇突之处, 时足惊人, 间以徘谐, 亦常俊绝, 殊非同时作 手所敢也。

But the story is urbane and charmingly written, abounding in imaginative detail. Some of the fantasies are fresh and original and there are delightful touches of humour. In these respects Tung Yueh shows greater talent than any of his contemporaries.

(Lu, 2011: 176. Trans. Lu, 2000: 217)

In terms of BL (Boys Love), or its Chinese equivalent 耽美 danmei (Lit. 'addicted to beauty' or 'indulgence in beauty'), it is a contemporary literary genre derived from a Japanese subculture (McLelland, 2000, 2009, 2017; McLelland \& Welker, 2015; Welker, 2015), which features male-male same-sex romance and eroticism between adolescent boys and youthful men (Chao, 2016; Yang \& Xu, 2016, 2017a, 2017b; Zhang, 2016). Since entering China's niche market in the mid-1990s (Liu, 2009; Yang \& Bao, 2012), the BL genre has attracted legions of producers and consumers, the vast majority of whom are surmised to be heterosexual pubescent girls and adult women (Galbraith, 2015; Hester, 2015; Nagaike, 2015; Chao, 2017). BL fiction functions as the most-consumed subcategory of the genre (Wei, 2014), yet BL producers all write and publish under pseudonyms for self-protection (Xu \& Yang, 2013; Zeng, 2017), in that BL wring is subject to stringent government censorship and surveillance due to its homosexual essence and correlation with obscenity (Yi, 2013; Ng, 2015; McLelland, 2005, 2016; Wang, 2019). Chinese BL fiction manifests a patent dichotomy between 攻 gong 'seme' (top; insertive) and 受 shou 'uke' (bottom; receptive) roles, impinged upon by the Japanese BL subculture (Pagliassotti, 2010; Zhang, 2016; Yang \& Xu, 2017b).

In this research, I propound that Mirrors may be regarded as a prototypical paradigm of contemporary online fiction in a subgenre dubbed as 快穿 kuaichuan 'Quick Transmigration', and the similitude between Mirrors and Quick 
Transmigration literary works in China's cyberspace lies in their analogous settings, plots and characters. The first Quick Transmigration work, as far as I am aware of, is a 2007 novel 寻找前世之旅 Xuzhao Qianshi Zhi Lü 'Journey in Search of Previous Incarnations' (Trans. Mine) published by a writer pseudonymised Vivibear; this novel falls into the genre of 言情 yanqing 'romance' or BG 'boy-girl', viz. an Internet neologism denoting heterosexual-oriented literature within a heteronormative framework. Similarly, a horror-themed novel 无限恐怖 Wuxian Kongbu 'Endless Dread' (Trans. Mine) released online in 2007 is also characterised by the design of Quick Transmigration. Followed by these pioneering works, myriads of Quick Transmigration narratives have been composed, yet they have not attained deserved scholarly attention.

\section{Settings}

In Mirrors, the construal of time is constituted of three contemporaneous layers, viz. a World of the Ancients, a World of the Future and a World of Oblivion (Schulz, 1978). Moreover, the entire account is comprised of adventures in disparate fantasy worlds, reveries provoked by enticement, as well as the dyad between the protagonist and his double (Li, 2004: 103).

In digital literature, Quick Transmigration can be regarded as a subgenre of 'Time-Travel' (穿越 Chuanyue), yet the former is characterised by multiple settings with temporal and spatial divergences and transient exploration of each setting, as indicated by its name. In this sense, I posit that Mirrors bears recumbence to fiction of the Quick Transmigration subgenre. For instance, an online BL novel 快穿之打脸 狂魔 Kuaichuan Zhi Dalian Kuangmo 'Quick Transmigration: A Hacker's Revenge' (Trans. Mine) composed by 风流书呆 Fengliushudai concerns adventures of the protagonist and his same-sex partner in a profusion of worlds, as shown in Example (2) that is extracted the introductory page (文案 wenan).

(2) 顶尖黑客被主神选中当了几百近千世的反派, 每一世都不得不狂奔在作死的大道上, 落得 个悲惨收场。终于摆脱了反派系统的控制, 他决定复仇、虐渣、改变命运。

A top hacker was chosen to play villains in hundreds of incarnations, and in every incarnation, he was forced to behave recklessly and doomed to tragedy. Now, he is finally free of control and ready to take revenge and change fate.

(Quick Transmigration: A Hacker's Revenge. Introduction. Trans. Mine)

Analogously, according to the introduction of 那些和人生赢家抢男主的日子 Naxie He Renshengyingjia Qiang Nanzhude Rizi 'Rescuing Players from Big Bosses' (Trans. Mine) by 五色龙章 Wuselongzhang, the settings are constituted of a veritable cornucopia of eras and countries (Example (3)). Additionally, the introduction elaborates the rationale behind time travel in the narrative, i.e. via a massively multiplayer online role-playing game (Example (3)), which can be deemed as the modern counterpart of the Tower of Myriad Mirrors.

(3) 本文以后就可以分卷为: “和霸道兽人抢男人的日子” “和霸道帝王抢男人的日子” “和霸道 教皇抢男人的日子”“和霸道总裁抢男人的日子” “和魔教教主抢男人的日子” etc.总之专业拯 救落入霸道 XX 手里的小受,什么日久生情, 什么强取豪夺, 什么你只能做我龙傲天的男人, 在我 
手里一律都要被打脸。快穿流,伪无限流,世界观承接《一点不科学》, 人类可以通过仙界大型 网游随意穿越不同世界。本文主受, 主角邵宗严就是拯救遇难穿越者的救生员,真爱是只普通 低调的草鱼精,不是自带被强取豪夺光环的穿越受众。

This text can be divided into 'rescuing a man from a bossy orc', 'rescuing a man from a bossy emperor', 'rescuing a man from a bossy pope', 'rescuing a man from a bossy CEO', 'rescuing a man from a demonic sect master', etc. In a word, it is about professional rescue of ukes from bossy semes-nobody can force others by bullying, captivity or moral coercion. The novel belongs to Quick Transmigration and the rationale is the same as my other novel It's Not Rational at All, namely, human beings can freely travel to various worlds via a massively multiplayer online role-playing game. The protagonist is a uke who saves time-travellers from dangers, and his beloved is a low-profile fish spirit, not those victims of bullies.

(Rescuing Players from Big Bosses. Introduction. Trans. Mine)

Parallel to Mirrors that encompasses a World of the Ancients, a World of the Future and a World of Oblivion, Quick Transmigration fiction is predominantly comprised of worlds concerning past, present and future time points as well as illusory worlds. Apart from novels Quick Transmigration: A Hacker's Revenge and Rescuing Players from Big Bosses, there is a prodigious amount of similar literary works, such as 快穿之完美命运 Kuaichuang Zhi Wanmei Mingyun 'Quick Transmigration: Perfect Fate' by 西子绪 Xizixu, which has different settings in venues embedded in imperial and modern China, Eastern and Western fantasy worlds against religious background, an apocalyptic world replete with zombies, a future universe with star wars and A/B/O dynamics (Alpha/Beta/Omega), etc. It is notable that parallel to Mirrors, protagonists and their same-sex partners in $\mathrm{BL}$ Quick Transmigration writing also return to their original world at the ending.

\section{Storylines}

In Mirrors, the Monkey serves in place of King Yama as the judge of Hell, so he rejudges a well-established Song dynasty case concerning a notoriously treasonable prime minister 秦桧 Qin Hui (1091-1155) who persecuted and executed a loyal general 岳飞 Yue Fei (1103-1141) (Chu 1997). Chapter 9 of the narrative abounds with a wide range of barbarous torture of Qin Hui, as shown by the explicit, imageryprovoking depictions in Example (4).

(4) 一百五十名铁面鬼即时应声, 取出六百万只绣花针，把秦桧遍身刺到...两个蓬头猛鬼抬 出小刀山, 把一个秦桧血淋淋拖将上去...白面精灵鬼一百名得令, 顷刻排上五丈长、一百丈 阔一张碓子, 把秦桧碓成桃花红粉水...把秦桧滚油海里洗浴; 拆开两胁, 做成四翼, 变作蜻蜓 模样...便叫二百名钻子鬼扛出一坛人脓水, 灌入秦桧口中...登时又叫金爪精鬼取锯子过来, 缚定秦桧, 解成万片...叫五千名铜骨鬼使, 抬出一座铁泰山, 压在秦桧背上....登时著一百名蓬 头鬼扛出火灶, 铸起十二面金牌。帘外擂鼓一通, 堦出无数青面獠牙鬼, 拥住秦桧, 先別一个 “鱼鳞样”, 一片一片别来, 一齐投入火灶...

One hundred and fifty iron-faced devils assented immediately and produced six million embroidery needles, pushing them everywhere into Ch'in K'uai's body...Two fierce tumbleweed-haired devils brought out a hill-shaped device bristling with knife blades. They threw Ch'in K'uai onto it, and his body dripped with blood...A hundred intelligent white-faced devils received the command and shortly brought out a pestle fifty feet long and one hundred feet wide and crushed Ch'in K'uai into peach-blossom-pink paste...He ordered the Barons of Light and Dark from the Board of Baleful Heaven to wash Ch'in K'uai in the Sea of Boiling Oil. They tore open his ribs and made them into four wings, changing

Logos et Littera: Journal of Interdisciplinary Approaches to Text 
him into a dragonfly...He ordered two hundred Drill Devils to carry out a vat of human pus and pour it into Ch'in K'uai's mouth...He ordered the gold-clawed expert devils to bring a saw, tie Ch'in K'uai down and saw him into ten thousand pieces...He ordered five thousand copper-boned devils to bring out an iron Mount T'ai and press it on Ch'in K'uai's back...He immediately ordered a hundred tumbleweed-haired devils to bring out a furnace and forge twelve golden tablets. Outside the screen the drum was beaten three hundred and thirtythree times. Countless green-faced long-fanged devils charged in and grabbed hold of Ch'in K'uai. First they hacked him into sections like fish scales, then cut them off piece by piece and threw them in the furnace...

(Tower of Myriad Mirrors. Chapter 9. Trans. Lin \& Schulz, 1978: 106-117)

Through painting a vivid portrait of the excruciating Qin Hui in graphic detail, the author not only conveys his deep loathing towards the abhorrent traitor, but also ingratiates himself with readers who share the same odium and are disposed to enjoy the reverie. In this sense, Mirrors bears similitude to Internet 爽文 shuangwen 'feel-good writing' that enhances reading pleasure through quasi-reverie, surrealistic plots and depictions.

BL Quick Transmigration fiction in contemporary Chinese virtual literature also abounds in depictions that are consistent with elements of 'feel-good writing'. For instance, a novel entitled 不要在垃圾桶里捡男朋友 Buyaozai Lajitongli Jian Nanpengyou 'Don't Find Boyfriends from Dumps' composed by 骑鲸南去 Qijingnanqu is an exemplary feel-good narrative, in which tortured ukes are possessed by the time-travelling protagonist who controls their bodies to exact revenge on their repugnant semes. As indicated by the introduction, the narrative expatiates various victims' retaliation as well as predators' defamation, repentance and retribution (Example (5)), thereby accommodating readers' values and expectations and hence reading enjoyment.

(5) 061: 你好, 渣攻回收系统了解一下。本系统以渣攻的悔意值为计量单位, 每积攒一百悔意 值即可脱离当前世界。友情提示一下，我们的员工在工作中一般是通过自我奉献与牺牲，培 养渣攻的依赖性, 一步步让渣攻离不开...池小池: 身败名裂算多少后悔值? 跌落神坛算多少后 悔值? 求而不得算多少后悔值?

Number 061 said: 'Hi, this is a system for bad semes. The system calculates bad semes' regret indexes. When the regret figure reaches 100, you can leave this world for the next. I'll give you a practical tip: Most of our revengers choose to nurture semes' dependence through selfless sacrifice, so that those bad semes will regret mistreating them...' Chi Xiaochi asked: 'How about ruining their reputation? How about annihilating their status? How about leaving them in a lifelong sense of loss?'

(Don't Find Boyfriends from Dumps. Introduction. Trans. Mine)

Furthermore, I posit that Mirrors is featured by a narrative device dubbed as 金手指 jin shouzhi 'golden finger': in male-authored/oriented, blatantly-presented fantasies, especially those unflatteringly referred to as 种马文 zhongma 'stud fiction', male protagonists are always blessed with 'golden finger', viz. invincible prowess to conquer the world as well as stud-like virility to attract numerous beautiful women (Feng, 2013: 10, 38, 93). As a consequence of this property, some Chinese Webbased novels are nicknamed YY 小说 YY xiaoshuo 'YY fiction', in which YY denotes 意 淫 yiyin 'lust of the mind' and describes explicit exploration of libidinous mental 
fulfilment (Chao, 2012: 225; Hockx, 2015: 112). Although the Monkey in Mirrors is not depicted to have emotional and sexual entanglements, his adventure is facilitated by the authorial 'golden finger'. For instance, the plot line of Chapter 10 can be summarised by its title, namely, 'Monkey returns to the Tower of Myriad Mirrors; In the Palace of Creeping Vines Wu-k'ung saves himself' (万镜台行者重归 葛葸宫悟空自救 Wanjingtai Xingzhe chonggui Geleigong Wukong zijiu) (Lin \& Schulz, 1978: 123). Nevertheless, as can be seen from Example (6), the Monkey's successful return to the Tower of Myriad Mirrors is owing to the guide of the New Ancient, and his seeming self-rescue is impossible without the good deed of an old man. The facilitation of both supporting characters in Example (6) serves as the 'golden finger' created exclusively for the protagonist.

(6) 新古人道: “既如此, 随我来, 随我来!”一只手扯了行者, 拽脚便走。走到一池绿水边, 新古 人更不打话, 把行者辘轳轳一推, 喇赖一声, 端原跌在万镜楼中...行者哀告原由。老人道: “你 却不知, 此处是个青青世界小月王宫里。他原是书生出身, 做了国王, 便镇日作风华事业, 造 起十三宫, 配著十三经; 这里是六十四卦宫。你一时昏乱, 当当走入困之困葛葸宫中, 所以被 他捆住。我替你解下红线, 放你去寻师父。” 行者含泪道: “若得翁长如此, 感谢不尽。” 老人 即时用手一根一根扯断红线。

The New Ancient said, 'If that's the case, follow me! Follow me!!' He took Monkey with one hand and dragged him along until they came to a pool of blue water. Without uttering a word the New Ancient pushed Monkey, and splash! he fell right into the Tower of Myriad Mirrors...After Monkey had moaned the reasons, the old man said, 'You don't realize that this is the palace of the Little Moon King in the Green Green World. Once he was a student. Later when he became a king he spent his days in dissipation. He built thirteen palaces, corresponding to the thirteen classics. This is the Sixty-four Hexagram Palace. When you became confused, you walked directly into the Palace of Entangling Vines of the Hexagram Oppression and were bound tight. I'll loosen the red threads for you and let you go search for your Master.' With tears in his eyes Monkey said, 'If you can do this, Elder, I'll never be able to thank you enough.' The old man straightaway snapped the red threads one by one with his hands.

(Tower of Myriad Mirrors. Chapter 10. Trans. Lin \& Schulz, 1978: 128-129)

Analogously, in BL Quick Transmigration novels, a considerable proportion of seme and uke protagonists can easily attain sympathy and assistance bestowed by the 'golden finger'. However, disparate from the depictions in Example (6), the preponderant reason why protagonists in BL fiction enjoy privileges lies in their supreme demeanour, which can be reflected by the name of the genre, viz. 'addicted to beauty; indulgence in beauty'. For instance, in 快穿之不死病人 Kuaichuan Zhi Busi Bingren 'Quick Transmigration: An Immoral Patient' by 阿辞姑娘 Aciguniang, the protagonist is easily forgiven due to his outstanding appearance.

Apart from external facilitation, the protagonist in Mirrors also possesses competence and fortuitousness. As can be seen from Example (7), the Monkey effortlessly 'exterminates the six thieves' (Trans. Lin \& Schulz, 1978: 97), which encapsulates his invincible prowess; additionally, his substitution of Emperor Yen-lo governing the Underworld indicates his fortuitous opportunity.

(7) 行者道: “我放得你, 你却放不得我!” 登时拔出棒来, 打为肉饼。望前便走,一心要寻伏道。 忽然一对青衣童子一把扯住行者, 道: “大圣爷来得好, 来得好! 我们阎罗天子得病而亡, 上帝有 
些起工动作之忙, 没得工夫派出姓氏, 竟不管阴司无主。今日大圣爷替我们权管半日, 极为感 激!"

Monkey said, 'I could spare you, but you wouldn't spare me.' And he brought down his cudgel and pounded the thieves to meat cakes. Then he walked away, intent on finding the hidden path. All at once a pair of boys wearing blue grabbed Monkey and said, 'You've come just in time, my Lord Great Sage. Our Emperor Yen-lo became ill and died. The Jade Emperor is busy with some kind of construction work and didn't have time to send anyone-he didn't care that the Underworld had no master. If my Lord Great Sage could take charge for us for only half a day, we would be most grateful.'

(Tower of Myriad Mirrors. Chapter 8. Trans. Lin \& Schulz, 1978: 97-98)

Similarly, both seme and uke protagonists in BL Quick Transmigration novels are equipped with 'golden finger' elements such as aptitude and luck. For instance, in 超级大脑 Chaoji Danao 'Super Brain' composed by 梦千航 Mengqianhang, the protagonist has an excellent memory and learning abilities, rendering the narrative a typical piece of 'feel-good writing'.

\section{Characters}

In Mirrors, when the Monkey enters the World of Ancients, he assumes the appearance of 虞美人 $\mathrm{Yu}$ Meiren 'Beauty $\mathrm{Yu}$ ' so as to locate a magic weapon and Emperor Qin Shi Huang (259-210 BC), whereas after deceiving Beauty Yu's husband 项羽 Xiang Yu 'King Hsiang Yü' (232-202 BC) into killing the real woman. Although the prompt switches of roles in the World of the Ancients triggers the Monkey's puzzlement concerning truth and falsehood, he experiences adoration and tenderness from Xiang Yu and appreciates Xiang Yu's loyalty to love and human bonds. As a consequence of a sense of human attachment, the Monkey's 'emotional vigor increases as he experiences more intimate relationships and more intense feelings' (Chu, 1997: 660). I propound that being a man disguised as a woman, the Monkey is not completely void of devotion to Xiang Yu, as shown in Example (8). Given the fact that male-male emotional intimacy and sexual intercourse were comprehensively tolerated during most historical periods in imperial China (Ruan \& Tsai, 1987; Hinsch, 1990; Ruan, 1991; Louie, 2002, 2012), it is plausible to surmise that the author implies a homosexual bond between the two characters. That is to say, the desire embodied by Qing Fish fundamentally denotes male-male homosexual desire.

(8) 项羽大惊, 慌忙踠下。行者背转, 项羽又飞趋踠在行者面前, 叫: “美人, 可怜你枕席之人, 聊 开笑面!” 行者也不做声。项羽无奈, 只得陪哭。行者方才红著桃花脸儿, 指著项羽道: “顽贼! 你为赫赫将军, 不能庇一女子, 有何颜面坐此高台!” 项羽只是哭, 也不敢答应。行者微露不忍 之态, 用手扶起, 道: “常言道: ‘男儿两膝有黄金。’你今后不可乱跍!”

Hsiang Yü was startled and fell to his knees. Monkey turned his back. Hsiang Yü flew over to kneel in front of Monkey and said, 'Beautiful Lady, have pity on your bedfellow! Please, a little smile!' When Monkey didn't say anything, Hsiang Yü could do nothing but cry along with her. Then Monkey's face became red as a peach blossom. He pointed at Hsiang Yü and said, 'Stupid thief! The terrible general and you can't even protect a girl! How can you have the face to sit on this high platform?' Hsiang Yü only cried and didn't dare reply. Monkey put on a look of pity. He helped him up and said, 'It's often said there's yellow gold on a man's knees. After this you really mustn't kneel without call.'

(Tower of Myriad Mirrors. Chapter 6. Trans. Lin \& Schulz, 1978: 75)

Logos et Littera: Journal of Interdisciplinary Approaches to Text 
In Xizixu's another horror-themed BL novel 死亡万花筒 Siwang Wanhuatong 'Kaleidoscope of Death', the seme protagonist is tagged as a 女装大佬 nüzhuang dalao 'cross-dressed mogul', namely, a man enjoying transvestism; the uke protagonist is also persuaded into cross-dressing in some time-travel adventures while they are establishing a close bond. Practices of transvestism can be attested in other BL Quick Transmigration novels, exemplified by 全能攻略游戏 Quanneng Gonglüe Youxi 'Almighty Game' by 公子如兰 Gongzirulan.

It is worth mentioning that the author of Mirrors also composes a Q\&A section to address a list of questions, ranging from those pertaining to the creation purpose 'Journey to the West is not incomplete; why a supplement?' (Lin \& Schulz, 1978: 191) to those concerning inexplicable plots 'The Great Sage suddenly has a wife and children. How is this?' (Lin \& Schulz, 1978: 194); following each question, the author provides detailed and logical elaboration in various lengths. This design also functions as a salient attribute of a myriad of BL Quick Transmigration novels. On 晋江文学城 Jinjiang Wenxue Cheng 'Jinjiang Literature City', a pioneering and leading female-oriented online platform accommodating BL texts (Feng, 2009, 2013; Xu \& Yang, 2013; Zheng, 2019), there is a section called 作者有话要说 zuozhe youhua yaoshuo 'author's words' that is a dedicated space set off from the main text to display authorial comments and responses to readers' remarks; this section serves as a means of communication between authors and their readerships, analogous to the Q\&A section in Mirrors. For instance, in the 'author's words' section of 炮灰为王 Paohui Weiwang 'Cannon Fodder as the King', the author pseudonymised 甲子亥 Jiazihai interacts with readers by means of inviting comments, answering enquires and advertising new works. That is to say, the inclusion of a Q\&A section in Mirrors might have inspired contemporary writers of BL Quick Transmigration fiction.

\section{Conclusion}

In addition to imagination, satire and Buddhism, Mirrors exhibits psychological insights and inscrutable dreams. More significantly, it can be regarded as a prototypical BL novel under the genre of Quick Transmigration. Albeit being a classical novel composed in late Ming, it bears resemblance to contemporary fiction in China's cyber space. First, parallel to BL Quick Transmigration works, settings of Mirrors are constituted of multiple contemporaneous layers, viz. past, present and future time points as well as illusory worlds. Second, both Mirrors and its modern counterparts fall into the category of 'feel-good writing' and entail depictions appertaining to the narrative device of 'golden finger'. Third, the Monkey's emotional entanglement with Xiang $\mathrm{Yu}$ is similar to that in BL fiction, especially those with transvestism depictions. Moreover, the author of Mirrors deploys a Q\&A section to expound on the rationale behind the narrative, analogous to his contemporary successors who interact with their readerships in a virtual context.

Logos et Littera: Journal of Interdisciplinary Approaches to Text 


\section{References}

Bantly, Francisca Cho. Buddhist Allegory in the Journey to the West. The Journal of Asian Studies 48.3 (1989): 512-524.

Chao, Shih-chen. Desire and Fantasy On-Line: A Sociological and Psychoanalytical Approach to the Prosumption of Chinese Internet Fiction. PhD thesis. University of Manchester, 2012.

Chao, Shih-chen. Grotesque Eroticism in the Danmei Genre: The Case of Lucifer's Club in Chinese Cyberspace. Porn Studies 3.1 (2016): 65-76.

Chao, Shih-chen. Cosplay, Cuteness, and Weiniang: The Queered Ke'ai of MaleCosplayers as 'Fake Girls'. Boys' Love, Cosplay, and Androgynous Idols: Queer Fan Cultures in Mainland China, Hong Kong, and Taiwan, eds. Lavin Maud, Ling Yang and Jamie Jing Zhao. Hong Kong: Hong Kong University Press. 2017. 20-44.

Cheng, Eileen J. Literary Remains: Death, Trauma, and Lu Xun's Refusal to Mourn. Honolulu: University of Hawaii Press, 2013.

Chu, Madeline. Journey into Desire: Monkey's Secular Experience in the Xiyoubu. Journal of the American Oriental Society 117.4 (1997): 654-664.

Dong, Lijie. 论《西游补》的解构主义特征 Lun Xiyoubu de jiegou zhuyi tezheng [On the deconstructionist features of A supplement to Journey to the west]. Journal of Language and Literature Studies 07 (2015).

Feng, Jin. 'Addicted to Beauty': Consuming and Producing Web-Based Chinese Danmei Fiction at Jinjiang. Modern Chinese Literature and Culture 21.2 (2009): 1-41.

Feng, Jin. Romancing the internet: Producing and consuming Chinese web romance. Danvers, MA: Brill, 2013.

Fu, Chengzhou. 《西游补》作者董斯张考 Xiyoubu zuozhe Dong Sizhang kao [On the author of A supplement to Journey to the west Dong Sizhang]. Literature heritage 03 (1989).

Fu, Chengzhou. 董斯张《西游补》原本十五回考 Dong Sizhang Xiyoubu yuanben wushi hui kao [The original 15 chapters of Dong Sizhang's A supplement to Journey to the west]. Wen Xian 01 (2006): 127-130.

Galbraith, Patrick W. Moe talk: Affective communication among female fans of yaoi in Japan. Boys Love Manga and Beyond: History, Culture, and Community in Japan, Eds. Mark McLelland, Kazumi Nagaike, Katsuhiko Suganuma and James Welker, Jackson: University Press of Mississippi. 2015. 153-168.

Gao, Rihui and Tianni Jin. 《西游补》与禅宗 “三境界” Xiyoubu yu chanzong ‘sanjingjie’ [A supplement to Journey to the west and three Buddhist levels]. Journal of Dalian University 02 (2020).

Han, Hongju. 董说《西游补》的版本、序咙考辩 Dong Yue Xiyoubu de banben xuba kaobian [On the edition and preface of Dong Yue's A Supplement to Journey to the West]. Journal of Zhejiang Normal University 05 (2014).

Harpham, John Samuel. 'A Fierce Silence Falls': Lu Xun's Call to Arms. Criticism 55.1 (2013): 95-118.

Hegel, Robert E. The Tower of Myriad Mirrors: A Supplement to Journey to the West by Tung Yüeh, Shuen-fu Lin and Larry J. Schulz. Chinese Literature: Essays, Articles, Reviews 4.1 (1982): 140.

Hester, Jeffry T.. Fujoshi emergent: Shifting popular representations of yaoi/BL fandom in Japan. Boys Love Manga and Beyond: History, Culture, and Community in Japan, Eds. Mark McLelland, Kazumi Nagaike, Katsuhiko Suganuma and James Welker. Jackson: University Press of Mississippi. 2015. 169-189.

Hinsch, Bret. Passions of the Cut Sleeve: The Male Homosexual Tradition in China. Berkeley: University of California Press, 1990.

Hockx, Michel. Internet Literature in China. New York: Columbia University Press, 2015.

Hsia, Chih-tsing. C. T. Hsia on Chinese Literature. New York: Columbia University Press, 2004.

Hsia, Chih-tsing. The Classic Chinese Novel: A Critical Introduction. Hong Kong: The Chinese University Press, 2015.

Hsia, Chih-tsing. and T. A. Hsia. New Perspectives on Two Ming Novels: Hsi-yu chi and Hsi-yu pu. Wen-lin: Studies in the Chinese Humanities, ed. Tse-tsung Chow, Madison: University of Wisconsin Press. 1968.

Hsia, T. A. Hsi-yu pu. In Wen-lin: Studies in the Chinese Humanities, ed. Tse-tsung Chow, Madison: University of Wisconsin Press. 1968.

Logos et Littera: Journal of Interdisciplinary Approaches to Text 
Hua, Mengyu. 《西游补》的“无名焦虑” 与梦境书写初探 Xiyoubu de “wuming jiaolv' yu mengjing shuxie chutan [Discussion on the 'Nameless worry' and dreams in A Supplement to Journey to the West]. Journal of China University of Petroleum: 05 (2019).

Hui, Andrew. Wordless Texts, Empty Hands: The Metaphysics and Materiality of Scriptures in 'Journey to the West'. Harvard Journal of Asiatic Studies 75.1 (2015): 1-28.

Jones, Andrew F. Developmental Fairy Tales: Evolutionary Thinking and Modern Chinese Culture. Cambridge and London: Harvard University Press, 2011.

Li, Mengyuan. 论《西游补》的视觉现代性之维 Lun Xiyoubu de shijue xiandaixing zhiwei [On the modern visual representation of A Supplement to Journey to the West]. Theory Horizon 08 (2015).

Li, Qiancheng. Fictions of Enlightenment: Journey to the West, Tower of Myriad Mirrors, and Dream of the Red Chamber. Honolulu: University of Hawaii Press, 2004.

$\mathrm{Li}$, Yang. 浅析《西游补》中的宗教内蕴 Qianxi Xiyoubu zhongde zongjiao neihan [Analysis of religious representation in A Supplement to Journey to the West]. Cultural Journal 02 (2021).

Lin, Shuen-fu and Larry Schulz. Trans. Tower of Myriad Mirrors: A Supplement to Journey to the West. By Tung Yueh. Berkeley, California: Asian Humanities Press, 1978.

Liu, Mengying. 《后西游记》社会称谓语之文化透视 Hou Xiyouji shehui chengwei zhi wenhua toushi [The Social Appellations and Its Culture of After the Journey to the West]. Journal of Hebei Energy Institute of Vocation and Technology 78.1 (2020): 28-31.

Liu, Yinbai. 《续西游记》作者推考 Xu Xiyouji zuozhe tuikao [Speculation about the author of Sequel to Journey to the West]. Social Science in Yunnan (1984): 106-107.

Lu, Hsun. A Brief History of Chinese Fiction. Honolulu, Hawaii: University Press of the Pacific, 2000.

$\mathrm{Lu}$, Xun. 中國小說史略; 漢文學史網要 Zhongguo xiaoshuo shilve; Han wenxueshi gangyao [History of Chinese fiction; Introduction of history of Han literary]. New Taipei City: Shin Sho Sha, 2011.

McLelland, Mark. The Love Between 'Beautiful Boys' in Japanese Women's Comics. Journal of Gender Studies 9.1 (2000): 13-25.

McLelland, Mark. The World of Yaoi: The internet, censorship and the global 'boys' love' fandom. Australian Feminist Law Journal 23.1 (2005): 61-77.

McLelland, Mark. (A)cute Confusion: The Unpredictable Journey of Japanese Popular Culture. Intersections: Gender and Sexuality in Asia and the Pacific 20 (2009).

McLelland, Mark. New Media, Censorship and Gender: Using Obscenity Law to Restrict Online SelfExpression in Japan and China. Routledge Handbook of New Media in Asia, eds. Larissa Hjorth and Olivia Khoo, Abingdon: Routledge. 2016. 118-129.

McLelland, Mark. Introduction. The End of Cool Japan: Ethical, Legal, and Cultural Challenges to Japanese Popular Culture, ed. Mark McLelland, London: Routledge. 2017. 1-30.

McLelland, Mark and James Welker. An introduction to 'Boys Love' in Japan. Boys Love Manga and Beyond: History, Culture, and Community in Japan, Eds. Mark McLelland, Kazumi Nagaike, Katsuhiko Suganuma and James Welker, Jackson: University Press of Mississippi. 2015. 3-20.

Miao, Zhuang. 中国古代小说人物辞典 Zhongguo gudai xiaoshuo renwu cidian [Dictionery of characters in classical Chinese fiction]. Jinan: Qilu Press, 1991.

Nagaike, Kazumi. Do heterosexual men dream of homosexual Men?: BL fudanshi and discourse on male feminization. Boys Love Manga and Beyond: History, Culture, and Community in Japan, Eds. Mark McLelland, Kazumi Nagaike, Katsuhiko Suganuma and James Welker, Jackson: University Press of Mississippi. 2015. 199-209.

$\mathrm{Ng}$, Lynda. China's elusive truths: Censorship, value and literature in the Internet age. Censorship and the Limits of the Literary: A Global View, ed. Nichole Moore, New York, London: Bloomsbury. 2015. 233-246.

Ouyang, Siyu. 入 “镜” 与行者的颠倒梦想——浅析《西游补》中的情与梦认领 Rujing yu xingzhede diandao mengxiang-Qianxi Xiyoubu zhongde qing yu meng renling [The upside-down dream of the monkey-An analysis of qing and dreams in A Supplement to Journey to the West]. Data of Culture and Education 14 (2015): 3-5.

Pagliassotti, Dru. Better than romance? Japanese BL manga and the subgenre of male/male romantic fiction. Boys' love manga: Essays on the sexual ambiguity and cross-cultural fandom of the genre, eds. Antonia Levi, Mark McHarry and Dru Pagliassotti, Jefferson, NY: McFarland. 2010. 59-83.

Logos et Littera: Journal of Interdisciplinary Approaches to Text 
Plaks, Andrew. Allegory in Hsi-yu Chi and Hung-lou Meng. Chinese Narrative. Critical and Theoretical Essays, ed. Andrew Plaks, Princeton: Princeton University Press. 1977. 309-352.

Louie, Kam. Theorising Chinese masculinity: Society and gender in China. Cambridge, UK: Cambridge University Press, 2002.

Louie, Kam. Popular culture and masculinity ideals in East Asia, with special reference to China. The Journal of Asian Studies 71.4 (2012): 929-943.

Ruan, Fang-fu. Transvestism and Transsexualism. In Sex in China. Perspectives in Sexuality (Behavior, Research, and Therapy). Boston, MA: Springer, 1991.

Ruan, Fang-fu and Yung-mei Tsai. Male homosexuality in traditional Chinese literature. Journal of Homosexuality 14 (1987): 21-33.

Sang, Yu. 《续西游记》的故事源流 Xu Xiyouji de gushi yuanyuan [Source of stories in Sequel to Journey to the West]. Northern Literature (2014): 33-34.

Schulz, Larry. Introduction. Tower of Myriad Mirrors: A Supplement to Journey to the West. By Tung Yueh. Trans. Shuen-fu Lin and Larry Schulz, Berkeley, California: Asian Humanities Press. 1978. 5-22.

Shep, Sydney J. Paper and Print Technology. The Encyclopedia of the Novel, Peter Melville Logan, Olakunle George, Susan Hegeman and Efraín Kristal, Chichester: John Wiley \& Sons. 2011. 596602.

Sun, Lung-Kee. To Be or Not to Be 'Eaten': Lu Xun's Dilemma of Political Engagement. Modern China 12.4 (1986): 459-485.

Tambling, Jeremy. Madmen and Other Survivors: Reading Lu Xun's Fiction. Hong Kong: Hong Kong University Press, 2007.

Wall, Barbara. Deconstruction of Ideological Discourses: Ch'oe Inhun's Sŏyugi (The Journey To The West, 西遊記) as a Parody of Xiyouji (The Journey To The West, 西遊記). Acta Koreana 20.1 (2017): 281-306.

Wang, Cathy Yue. Officially Sanctioned Adaptation and Affective Fan Resistance: The Transmedia Convergence of the Online Drama Guardian in China. International Journal of TV Serial Narratives (2019): 45-58.

Wang, Ding. 从《西游补》《斩鬼传》《儒林外史》三书看讽刺艺术 Cong Xiyoubu Zhanguizhuan Rulinwaishi sanshu kan fengci yishu [Analysing sarcasm in A Supplement to Journey to the West, Zhanguizhuan and Rulin Waishi]. Journal of Hunan First Normal College 01 (1999): 3943.

Wang, Feng Robin and Philippe Humblé. Analysis of the Buddhist Conversion of Great Sage: A corpusbased investigation of textual evidence from the English translation of The Journey to the West. Chinese Semiotic Studies 14.4 (2018): 505-527.

Wang, Feng Robin, Philippe Humblé and Wen Chen. A Bibliometric Analysis of Translation Studies: A Case Study on Chinese Canon The Journey to the West. SAGE Open 9.4 (2019). DOI: $10.1177 / 2158244019894268$.

Wang, Miao. 试析《西游补》的讽喻主题 Shixi Xiyoubu de fengyu zhuti [Analysis of the sarcastic theme of A Supplement to Journey to the West]. Journal of Jilin TV Radio University 09 (2014).

Wang, Pu. Lu Xun (Zhou Shuren). The Encyclopedia of Postcolonial Studies. https://doi.org/10.1002/9781119076506.wbeps214. 2016.

Wang, Qizhou. 中国通俗小说史 Zhongguo tongsu xiaoshuo shi [History of Chinese light fiction]. Wuhan: Wuhan University Press, 2015.

Wang, Yiyan. Paper and Print Technology. The Encyclopedia of the Novel, Peter Melville Logan, Olakunle George, Susan Hegeman and Efraín Kristal, Chichester: John Wiley \& Sons. 2011. 178188.

Wei, John. Queer Encounters between Iron Man and Chinese Boys' Love Fandom. Transformative Works and Cultures 17 (2014). https://doi.org/10.3983/twc.2014.0561.

Welker, James. A Brief History of Shōnen'ai, Yaoi, and Boys Love. Boys Love Manga and Beyond: History, Culture, and Community in Japan, Eds. Mark McLelland, Kazumi Nagaike, Katsuhiko Suganuma and James Welker, Jackson: University Press of Mississippi. 2015. 42-75.

Xia, Li. Perilous Journeys and Archetypal Encounters: Critical Observations on Chinese Travel Literature. Neohelicon 28 (2001): 247-260.

Logos et Littera: Journal of Interdisciplinary Approaches to Text 
$\mathrm{Xu}$, Yanrui and Ling Yang. Forbidden love: incest, generational conflict, and the erotics of power in Chinese BL fiction. Journal of Graphic Novels and Comics 4.1 (2013): 30-43.

Yang, Ling and Yanrui Xu. Danmei, Xianqing, and the making of a queer online public sphere in China. Communication and the Public 1.2 (2016): 251-256.

Yang, Ling and Yanrui Xu. 'The love that dare not speak its name': The fate of Chinese danmei communities in the 2014 anti-porn campaign. The End of Cool Japan: Ethical, Legal, and Cultural Challenges to Japanese Popular Culture, ed. Mark McLelland, London: Routledge. 2017a. 163-183.

Yang, Ling and Yanrui Xu. Chinese Danmei Fandom and Cultural Globalization from Below. Boys' Love, Cosplay, and Androgynous Idols: Queer Fan Cultures in Mainland China, Hong Kong, and Taiwan, eds. Lavin Maud, Ling Yang and Jamie Jing Zhao, Hong Kong: Hong Kong University Press. 2017b. 3-19.

Yi, Erika Junhui. Reflection on Chinese boys' love fans: An insider's view. Transformative Works and Culture 12 (2013). https://doi.org/10.3983/twc.2013.0424.

Yu, Shicun. 非常道 Feichang dao [Extraordinary sayings]. Hong Kong: Cosmos Books, 2006.

Zeng, Wenting. 浅析耽美文化传播过程——以网络传播和腐女角度分析 Qianxi danmei wenhua chuanbo guocheng-Yi wangluo chuanbo he funv jiaodu fenxi [Analysis of the spread process of danmei culture-From the aspects of Internet communication and rotten girls]. Chuanbo yu Banquan 44.1 (2017): 136-137.

Zhang, Yiwei. 明清 “西游故事” 续衍的文化重释 Mingqing 'xiyou gushi' xuyande wenhua chongshi [Cultural interpretation of sequels to Xiyou stories in Ming and Qing dynasties]. Hanyuyan Wenxue Yanjiu 02 (2019).

Zhang, Yiwei.《后西游记》在日本 Hou Xiyouji zai riben [After the Journey to the West in Japan]. Wen Wei Po. 22 October 2020. http://www.chinawriter.com.cn/n1/2020/1022/c41938731901832.html. 2020.

Zheng, Suwan. 《西游补》中的佛教思想体现 Xiyoubu zhongde fojiao sixiang tixian [Buddhist thought in A Supplement to Journey to the West]. Anhui Literature 421.8 (2018): 122-124.

Zhang, Chunyu. Loving Boys Twice as Much: Chinese Women's Paradoxical Fandom of 'Boys' Love' Fiction. Women's Studies in Communication 39.3 (2016): 249-267.

Zhao, Hongjuan. 《西游补》崇祯本十六幅插图的寓意与特征 Xiyoubu Chongzhenben shiliufu chatude yuyi yu tezheng [A Research on Sixteen Illustrations of the 1641 Novel Supplement to Journey to the west]. Journal of Ming-Qing Fiction Studies 02 (2020): 134-151.

Zheng, Xiqing. Survival and Migration Patterns of Chinese Online Media Fandoms. Transformative Works and Cultures 30 (2019). DOI: https://doi.org/10.3983/twc.2019.1805. 